\title{
Transcending Time to Redeem Humanity: Human Rights Education and the Holocaust
}

\author{
P. A. Lock ${ }^{1}$, M. A. Sullivan ${ }^{2, *}$ \\ ${ }^{1}$ Liberal Studies Department, University of Redlands, 92373, United States \\ ${ }^{2}$ School of Education, University of Redlands, Redlands, 92373, United States
}

\begin{abstract}
This article presents the results of a qualitative, phenomenological case study focused on teachers' perceptions about human rights education in light of the Holocaust. Results are based on interviews with six participants in a professional teacher program upholding human rights education. Data analysis reveals three core perceptions about human rights education: (a) human rights education is excluded from the curriculum, (b) focus on human rights is supported by Holocaust survivor testimony, and (c) teachers' perceptions about human rights education are strengthened through the "Freedom Writers Institute". This work is grounded in critical theory linked to social and educational justice. The study has relevance for secondary teachers of literature and history, and particularly for those who work with disenfranchised students.
\end{abstract}

Keywords Human Rights Education, Holocaust, Critical Pedagogy, Moral Reasoning

\section{Background}

As social justice advocates, we pursue human rights because we must. Social and educational justice and human rights activism arise because of the constant oppression against, and absence of that very phenomenon. As Boyles, Carusi, and Attick (2009) phrase it, "The concept of social justice in education indicates that schools and society are, and always have been, replete with injustice" (p. 30). Across time and across history, human rights workers and educators have fought against opposition, pushing back against those who would transgress basic freedoms for survival and core values of language and identity. That tension lies at the core of the research reported here.

The six teachers interviewed for this project are part of an infrastructure that enforces a "banking system" of education (Freire, 1970). This banking system regards teachers and students as adaptable, manageable beings. It enforces a passive student body relegated to regurgitating facts dispensed by teachers who are equally passive, and who are controlled by state-mandated curricula that stifles critical consciousness, negating both students' and teachers' fully lived humanity. This article features a research story, a case study about the perceptions of six teachers who strive to awaken in their students a respect for the human rights of the oppressed, the marginalized, and the disempowered.

Corresponding author:

alayne_sullivan@redlands.edu (M. A. Sullivan)

Published online at http://journal.sapub.org/edu

Copyright (C) 2011 Scientific \& Academic Publishing. All Rights Reserved
These teachers have been transformed through their involvement in the Freedom Writers Institute and work to awaken in their students an ontological vocation to be more fully human in embracing human rights through a study of the Holocaust.

\subsection{Critical Theory and Dialectical Consciousness}

Those who embrace critical social and educational justice theory do so with three core realizations. The first is a belief that education ought to foster teachers' and students' emergence of consciousness about the affairs of the world around them as well as critically-active involvement in shaping a better world. Akin with this first core belief is Freire's "problem-posing education", wherein students and teachers "develop their power to perceive critically the way they exist in the world with which and in which they find themselves; they come to see the world not as a static reality, but as a reality in process, in transformation" (2009, p. 58 , original italics). The second core realization is that we live in a world that distributes power and privilege unequally. The third is a belief in the potential of social justice activism to effect positive change in a world where human rights are denied. These fundamental principles are discussed by North (2008) who synthesizes work in social justice theory according to three related principles: (a) recognition of the validity of cultural groups' demands for respect and dignity, and recognition that social good needs to be redistributed; (b) that macro and micro levels of power and resources affect educational inequities, and (c) knowledge and action are required at multiple levels to address the levels of disparity. 
For the critical educator, this three-fold recognition prompts a dialectical awareness and a relational dynamic, linking individuals to the inequities of society. In their work on critical theory and action research, Carr and Kemmis (1983) refer to dialectical thinking as an "open and questioning form of thinking which demands reflection back and forth between part and whole...subject and object, being and becoming..." (p. 36). McLaren (1986; 2009) helps us realize that a dialectical understanding of schools regards them as sites that can be liberating and dominating; that is, they can foster a "banking model" of education or a liberatory pedagogy - one that is grounded in an examination of the underlying political, social, and economic foundations of society.

Giroux (1981) refers to "productive knowledge" and "directive knowledge" in his discussion of a dialectical mode of inquiry. A productive dialectical educational process encourages students and their teachers to recognize how differing forms of knowledge are valued, to explore why such differences exist, and how various groups within society are empowered or disempowered as a result. Emancipatory knowledge allows students to see how some social values can be distorted and oppressed. At the same time, this very knowledge creates the foundation for social justice to be enacted. A dialectical framework thus approaches all socially-based issues in terms of a relational dynamic or tension. In the dynamic realm of the classroom, such ideas are translated to plain-speaking reality when teachers and students actively explore circumstances in our world, particularly those where human rights are transgressed in blatant and often "normalized" ways. Such situations include community-based issues related to poverty and unequal opportunity, culture and identity issues, and, of course, historical realities that present glaring truths about whole-scale obliterations of life, as with the ugly perpetrations of the Holocaust.

Pragmatic and theoretical foundations of critical social-justice theory are offered in light of specific teachers' perceptions of human rights education. Their dialectical relationship with issues raised through the Freedom Writers Institute and mindfulness of the Holocaust sprang to conscious realization as they explored its depths over intensive professional seminars; here, the abstractions of critical theory came to life through the teachers' mindful realizations. Critical theory became critical realization, and intention to act with students. It is significant that fundamental tenets of the foundations of critical theory, in fact, came out of the Frankfurt School in Germany throughout the beginnings, duration, and aftermath of the horrors of the Holocaust in Nazi Germany. All members of this group were dedicated to social transformation through ongoing critique of societal structures with a goal of emancipating human beings. Horkheimer (1972), a key member of this group, writes, for example, about exploring interconnections between the economic life of society, the psychic development of the individual, and effecting transformations in the realm of culture.
Habermas (1979), and Marcuse (1968), speak of how critical social action must be grounded in compassion and our sense of the sufferings of others. Members of the Frankfurt School spoke of a "crisis of reason", of how strict reliance on a fact-based, scientific method excluded subjectivity and critical thinking, thus freezing both human beings and history. The driving passion of the group was its synergy around the transformational functions of dialectical thought, revealing the power of human activity as a driving force for shaping a society without injustice. Critical dialectical thought and action undermines conformity, the logic of standardization, and a dominating rationality. It is teachers within schools who translate such abstract theorizing to specific subjective critiques, moral questioning, and undermining of repressive power structures. It is teachers who can shape students' critical consciousness about society in their morally centered concern for human rights. As we turn to a discussion about morality and human rights, we are mindful of many whose work find its theoretical nucleus around ideas that have grown out of the Frankfurt School and related adherents (Arendt, 1958; Aronowitz, 2001; Bourdieu \& Passeron, 1992; Foucault, 1972; Greene, 1988).

\subsection{Moral Development, Social Reconstructionism and Human Rights Education}

In their constant awareness of the power structures that shape a societal fabric, social reconstructionists stress the need for students to critically question human rights violations, and challenge the status quo of the dominant society that has been transmitted to them via the educational system (Kanpol, 1999; McLaren, 1999). They are undertaking this work under constant challenge within an educational context of two major philosophies: perennialism and essentialism. These two philosophies have undergirded three dominant models of education: (a) the banking model (Freire, 1970; Giroux, 2009b; Shor \& Freire, 1987), (b) the didactic model (Paul, 1992; Paul \& Elder, 2002), and (c) the factory model (McNeil, 2009). Such systems of thinking view learning in a reductionist manner, where achievement has been equated with standardized test scores and results (Giroux, 2009; McNeil, 2009; Paul, 1992; Paul \& Elder, 2002), staying on the path provided for them by the dominant power group. Mills (2000) characterizes those who affect such hegemony as "the ones who determine their duty, as well as the duties of those beneath them. They are not merely following orders: they give the orders" (p. 286). Within such models a focus on moral reasoning can be dampened, even discouraged.

The Holocaust - as well as other genocides - calls on us to ask moral questions about our responsibilities in an interdependent world, to apply a critical examination of a society that systematically disgraces the human dignity of its citizens. Development of a moral consciousness entails a serious questioning of the societal strictures and freedoms that shape our interactions with one another - as individuals and as groups within a relational fabric. Moral reasoning is 
the basis of such a dialectic; bringing its core elements to mind in light of history reminds us of its inherently social and interpersonal nature and how often those precepts have been contradicted. It is teachers who can most effectively influence responsible critiques, shaping their students' moral consciousness toward mindful engagement with the world around them.

Kohlberg's work (1976) forwards a structural stage-developmental view of moral reasoning - one that adds depth to our argued emphasis on the importance of dialectical consciousness and its place in human rights education. According to Kohlberg's view, each one of six stages reveals a differing moral reasoning process about justice and interpersonal relations (Pekarsky, 1980; Shapiro $\&$ Stefkovich, 2005). At the more advanced levels - Stage 4 of Kohlberg's model for example - the welfare of the state is placed above all other values emphasizing obedience to established laws, respect for authority, and performance of one's duties so that the social order is maintained. A Stage 5 moral reasoning process recognizes that if one had to decide between protecting a life or breaking a law, the right to live would represent a moral right to be protected. At this "post-conventional level" individuals are often placed in a tense dialectical strain with societal laws if they are to support a morally just action that de-fends human rights. We are reminded of such tensions in the following scenarios.

During his final statement before sentencing, Adolf Eichmann stated that he was merely "acting on orders" (Moncour, 2007). Since the Nazi government had distorted accepted societal ethics and morals, placing the "well-being" of the state above all others, it had forced its citizens to reconceive the concept of good and evil. In this society, an individual like Eichmann was technically able to defend his actions as being ethical, moral, and just. Of course, many might perceive that two men named Adolf (i.e., Eichmann and Hitler) defined a legal and moral reasoning system to deliberately - and cruelly - negate the values and the very lives of millions of Jews and other "minorities". Such legally condoned systems that validate one set of values and negate others are not at all uncommon.

Since the beginning of the 20th Century, Rommel (1994) estimates that governments, including the Soviet Union, the People's Republic of China, and Nazi Germany, have murdered 170 million of their own citizens. The Armenian genocide of 1915 through 1918, (Adalian, 2009), the Rwanda genocide (Gourevitch, 2008), and the Sudan genocide (Genocide Intervention Network, 2009) all con-firm what C. Wright Mills (2009) claimed in his book, The Power Elite: "We learn from history that we cannot learn from it" (p. 23). Many human beings seem immobilized in the face of edicts that justify mass murder or defame character due to values deemed other than "the norm".

Various other phenomenon may convince us of the imponderable difficulties individual people and collectives face when challenging a status quo, or rule-enforced behavior. For example, Milgram's experiment, conducted in 1961 at Yale University three months after the start of the trial of German Nazi war criminal Adolf Eichmann, left him shaking his head in wonder at the extent to which average men obeyed "legitimate" authority, applying painful electric shocks to individuals who offered incorrect answers to questions (Harrison, 2004). As cited in Harrison (2004), Milgram commented, "If in this study, an anonymous experimenter could successfully command adults to subdue a 50-year old man and force on him painful electric shocks against his protests, one can only wonder what government, with its vastly greater authority and prestige, can command of its subjects" (pp. 1081-1082). In pointing to these scenarios, we remind ourselves of the importance of helping our students develop strength of moral character that would instinctively decry such outrages to the dignity of another.

Jorgenson (2006) submits that the moral psychology community has come to accept that "there are two types of moral reasoning, namely Kohlberg's justice and Gilligan's care" (p. 179). Perhaps it was care - about her own dignity and those of comrade citizens - that prompted Rosa Parks to refuse to sit at the back of that bus. Another stalwart example of moral action comes in the person of Dietrich Bonhoeffer, a Lutheran minister, whose opposition to the laws of his Nazi Germany are expressed in these words: "I pray for the defeat of my country, for I think that is the only possibility of paying for all the suffering that my country has caused the world" (Rankin, 2006, p. 115). Many now agree with the sentiment expressed by Martin Luther King, Jr., when he stated, "If your opponent has a conscience, then follow Gandhi and non-violence. But if your enemy has no conscience like Hitler, then follow Bonhoeffer" (as quoted in Rankin, 2006, p. 116). Perhaps those whose moral conscience is grounded in an ethic of care are more likely to fight against a power structure that disenfranchises, hurts, and/or murders human beings.

History has revealed heinous crimes against humanity but also individuals who have realized that critical thinking and dissent have not only promoted social change, but have also enabled citizens to become full participants in a democratic society (Gordon, 2008). Dreier (2006) has helped us appreciate that many ideas that were once considered outrageous, utopian, and impractical are today taken for granted; the radical ideas of one generation have often become the common sense of subsequent generations. Shiman and Fernekes (1999) argued that we must be prepared to act against injustice and be willing to assume responsibility for the well-being of our fellow humans. Morally conscious dissenters, ethically caring citizens - whichever way we phrase it - are convinced that the world needs their socially reconstructive dialectical energy. Teachers and students can productively explore the tensions of society as well. In now considering human rights education in light of the Holocaust, we touch ground in the classroom with key values that are essential to an educated citizenry.

\subsection{The Holocaust and Human Rights Education}

What the Nazis discovered is that human rights have ex- 
isted only when there has been a mechanism for enforcing them (Haas, 1988). After the Jews were stripped of their citizenship by the Nazis as part of the Nuremberg laws (Haas, 1998), they had no rights because there was no longer an institution to guarantee or deliver them. Haas (1988) stated that none of the institutions that would have been expected to defend Jews and other victims felt compelled to do so - "not religious institutions (with minor exceptions) nor humanitarian organizations nor lawyers nor doctors nor even the Western Allies" (p. 215). The victims were left to fend for themselves while the world stood silent.

The teaching of human rights should be focused on reducing the distance between learners and the historical contexts they explore. One approach to make this a reality is to study the personal and moral dilemmas that Holocaust survivors faced, engaging students in a personally and politically-intense dialectical relationship with moral consciousness. Students and teachers become invested in human rights education (HRE) when they care about individual dignity and the rights of all human beings (Print et al., 2008). HRE has been concerned with the educational process whereby people learn about those rights that are inherent in human nature and without which we cannot live as civilized human beings (Lohrenscheit, 2002). Tibbits' work (2002) reveals that an in-depth case study about an event such as the Holocaust can serve as an effective catalyst for examining human rights violations. Shiman and Fernekes (1999) discovered that HRE "requires students to grapple with questions related to ethnocentrism, relativism, universalism, responsibility, conflict, and justice [and the] study of the Holocaust and genocides can raise questions of moral and ethical responsibility that have national and global implications" (p. 55). Teaching human rights has meant teaching social responsibility as well.

HRE has been shaped by a shared commitment to a humane order and a belief that human beings have the capacity and the responsibility to make a difference; it has transformative potential (Andreopoulos, 2002). At its core, HRE has promoted an awareness of human rights and has given students opportunities to explore how human rights apply to private and public life. Lohrenscheit (2002) stated that HRE should lead to "an understanding of, and sympathy for, the concepts of democracy, justice, equality, freedom, solidarity, peace, dignity, and rights and responsibilities" (p. 178). HRE has required that students have needed to examine perspectives other than their own. This need has extended to the recognition that human rights problems have occurred not only in the past, or in foreign countries, but also within their own country and communities. HRE has asserted that students have needed experiences in schools that prepared them for participation in the complex and global community into which they have been born.

HRE has emphasized the development of empathy for the suffering and marginalization that has been manifested by courageous actions expended on behalf of any marginalized group (Shiman \& Fernekes, 1999). Ac-cording to Lenhart and Savolainen (2002), every student and teacher should understand the universal elements of human rights, as having been a basis for promoting social progress, better living conditions, and greater freedom. HRE would be evidenced by such outcomes as people being "morally inclusive," extending "fairness to others," allocating "resources to others who need such", and making "sacrifices that would foster their well-being" (Opotow, Gerson, \& Woodside, 2005, p. 306). Therefore, Print et al. (2008) argued, a person educated in human rights, making free, morally-based decisions and actions, could contribute towards social justice and hence the common good of all in society. More recent work by Peterson, (2010), Chyrikens \& Vieyra (2010), and Polak (2010) discusses the importance of human rights education through emphasis on Anne Frank, and the Holocaust; this work insists that these large stories of history must be held in mind so that their horrors cannot be repeated.

Most of the human rights themes, however, have required the questioning of established practices. As the first sentence of the Universal Declaration of Human Rights stated, respect for human rights and human dignity "is the foundation of freedom, justice and peace in the world" (United Nations, 2010). Human rights have emerged as the result of the identification of successive rights moving towards the inclusion of traditionally marginalized groups based on challenges made to the status quo within various historical time periods. Based on the equality of all human beings, "without distinction of any kind, such as race, color, sex, language, religion, political or other opinion, national or social origin, property, birth or other status" (United Nations, 1951), respecting human rights has the potential to effect radical social change. Embraced completely, human rights could result in the elimination of in-justice. In our current system of education with its em-phasis on a banking model and high test scores, human rights education - along with its underlying dialectical imperative - is often underemphasized. The teachers who participated in the study we report on view that oversight as egregious.

\section{Methodology}

\subsection{Research Context}

\section{In Auschwitz, I tell you, I did not feel I was a human being.}

\section{$\sim$ Renée Firestone}

The research study was designed to investigate teachers' perceptions of human rights education (HRE) in light of their involvement in the Freedom Writers Institute (FWI). Its work, led by Erin Gruwell, has gained fame through the film The Freedom Writers Diary. One of the key strands of work within the Institute is its featured emphasis on the testimony of Renée Firestone, an Auschwitz concentration-camp survivor. Dr. Firestone has become a passionate advocate of human rights education through her decades of work speaking about the Holocaust; those who hear her story are sensitized to the possibility that human hatred can 
arise at a societal level. Listeners often choose to keep her story alive and share it with others. The study's goal was to closely attend to the experiences of specific teachers who had attended the FWI - to study their experiential involvement in the various strands of the Institute's work, and particularly their engagement with Dr. Firestone's testimony.

The range of interview questions presented to the study's participants yielded insights about their social justice stances and the extent to which they felt compelled to further embed human rights education related to the Holocaust in their teaching. The study revealed a range of in-sights about the teachers' perceptions of the prevailing results-oriented paradigm within K-18 education. In-depth interviews yielded a level of dialectical thinking on the part of the teachers despite their perceived conscription within a banking model of education. The teachers' collectively shared a belief in the importance of facilitating their students' sensitivity about the Holocaust and about human rights in general. The nature of the study's design facilitated a range of insights about the teachers' moral stances and about their view of education. As the results indicate, these six teachers perceive that teaching for morality and human rights ought to be a core element of K-18 education.

\subsection{Research Strategy and Population Selection}

The qualitative phenomenological case study design facilitated an in-depth focus on the experiences of six teachers who completed the FWI program; it allowed in-sight about their responses to the Institute's emphasis on teaching for human rights. The primary researcher took on the role of participant-observer. This stance allowed him to see and feel what the six participants were experiencing and to generate different data sources, including observations and field notes, interviews that were recorded and transcribed for analysis, and analysis of documents related to the participants (McMillan \& Schumacher, 2006). A phenomenological research paradigm was adopted to plumb the core essence and shared experiences of the FWI for these specific teachers; the resulting data allowed a deep understanding of the teachers' consciousness about the Holocaust and human rights education.
In selecting the participants, purposeful sampling was used. Cresswell (2007) stated that a researcher selects individuals for a study because they can "purposefully inform an understanding of the research problem and central phenomenon in the study" (p. 125). This method led to the selection of teachers who participated in the professional development known as Freedom Writers Institute who met the following criteria:

1. Must be active K-18 educators

2. Must have personally heard Mrs. Renée Fire-stone's Holocaust survivor testimony;

3. Must have completed the Freedom Writers Institute. This phenomenological case study involved six Freedom Writer Teacher (FWT) participants: four females and two males. Two of the participants were involved in the pilot group of the FWI in 2006, two were from the 2007 FWI, one was from the $2008 \mathrm{FWI}$, and the final participant was involved in the FWI in 2009. Two of the participants live in the western United States, two live in the mid-western United States, and two live in the northeastern United States.

Participants were invited to participate in this study via the exclusive Freedom Writers Teacher website. As this secure Freedom Writer Teachers' (FWT) website is made available exclusively to teachers upon their completion of the Freedom Writers Institute (FWI), all teachers were considered as viable participants, since a primary focus of this study was teacher perceptions on the validity of this specific professional development. One emphasis of the FWI is the sense that all participants are immediately part of the Freedom Writer "family"; the primary researcher participated in this professional development, and worked with the approval of Erin Gruwell to conduct this research, creating and establishing an immediate access and rapport. Of the nine FWTs who responded, the six participants were selected based upon their location within the United States, as well as their year of original participation. This was done to help cover as much of a geographical area as possible, as well as to provide a longitudinal view. Table 1 discusses the stages and timeline of this portion of the study.

Table 1. Participant Involvement Timeline.

\begin{tabular}{|c|c|c|c|}
\hline Phase & Action & Time Frame & Follow Up \\
\hline $\begin{array}{c}\text { Invitation } \\
\text { to partici- } \\
\text { pate }\end{array}$ & $\begin{array}{c}\text { Posted invitation on FWT } \\
\text { website }\end{array}$ & $\begin{array}{c}\text { Two week window from } \\
\text { invitation to selecting par- } \\
\text { ticipants }\end{array}$ & $\begin{array}{c}\text { Interested participants contacted } \\
\text { primary researcher; emails were } \\
\text { sent to arrange interview times }\end{array}$ \\
\hline $\begin{array}{c}\text { Conducting } \\
\text { interviews }\end{array}$ & $\begin{array}{c}\text { Original contact made via } \\
\text { email; interviews conducted } \\
\text { via Skype (or email) }\end{array}$ & $\begin{array}{c}\text { Original interviews were } \\
\text { conducted within two } \\
\text { weeks of original contact }\end{array}$ & $\begin{array}{c}\text { Follow up questions (when neces- } \\
\text { sary) were conducted within one } \\
\text { week of original interview. (Two } \\
\text { participants were contacted a third } \\
\text { and fourth time, within two weeks } \\
\text { of original interview.) }\end{array}$ \\
\hline
\end{tabular}




\subsection{Data Collection and Analysis}

Each of the six participants responded to a set of ten questions in a semi-structured interview setting. In many cases, follow-up questions were presented to elaborate on the details they provided. Additional interviews were conducted to ensure the credibility of the research findings (McMillan \& Schumacher, 2006). A range of interviews were recorded with each participant; in some cases, these interviews were conducted through Skype. Validity of the findings was ensured by sharing transcribed interviews with each participant after being interviewed, and by finding a wide range of common themes and perceptions among the participants. During each interview, the primary researcher was taking notes to help provide follow-up clarifying responses and additional avenues of questioning.

The questions were developed in an attempt to solicit participants' perceptions into their practices and thoughts about their educational practices prior to, and following their involvement in the FWI. The order of the questions was established to help funnel perceptions from the more general to a more specific view of human rights education and the use and/or misuse of power in education - and how the former is influenced by the latter. Overall, it was interesting to note that the questions which discussed human rights education and power in society elicited the most passionate results from the participants. Table 2 outlines the ten questions that were asked of each participant.

All interviews were conducted within a four month period, from December 2009, through mid-March 2010. Teachers were eager and willing to share their perceptions and answers with the primary researcher. While most interviews were conducted via Skype, at times there were difficulties in arranging a time to conduct an interview - or in one case, the Skype program was continuously cutting off communication - and interviews were conducted via email. Surprisingly, it came to pass that interviews conducted via email correspondence provided more detailed answers from participants; participants reported they had more time to formulate and develop their responses.

While all six participants provided positive comments regarding their involvement in the FWI, there was a variation in their responses to other questions. Three of the participants heavily vocalized their concerns regarding the lack of a human-rights based educational approach within our schools, while the other three wanted to spend more time discussing their perceptions of the misuse of power in education. However, all six participants felt that the FWI provides a needed venue and educational approach to help correct what they perceived to be shortcomings in their respective foci.

Table 3 provides a brief framework outlining participants, means through which interviews were conducted, number of interviews, and primary data yielded.

Following interviews, responses were transcribed, and major themes/keywords were identified within the data. As successive interviews were con-ducted, themes from each interview were compared and contrasted, and when necessary, participants were contacted and asked for more detailed responses. Tables 4.1 and 4.2 highlight participants' reactions to questions presented in Table 2, as well as responses to hearing Holocaust survivor testimony, reactions to participation in the Freedom Writers Institute, and thoughts regarding the presence of human rights education in the school curriculum. Participants are identified by number. Tables 4.1 and 4.2 offer a breakdown of keywords and/or themes that were identified in the responses to each of the respective questions for each participant involved in this study.

Table 2. Interview Questions Asked of Each Participant.

\begin{tabular}{|ll|}
\hline 1. & What does human rights education mean to you? \\
\hline 2. & Please describe your experience of hearing Mrs. Firestone's personal testimony. \\
\hline 3. & If Mrs. Firestone's testimony impacted you and your work as a classroom teacher, could you please share this with me? \\
\hline 4. & Please share why you chose to become an active participant in the Freedom Writers Institute. \\
\hline 5. & Please share your reactions to participating in the Freedom Writers Institute. Has it had any influence on you as an educator? \\
\hline 6. & If your participation in the Freedom Writers Institute led you to change your relationships with students, please describe this change. \\
\hline 7. & What are your perceptions of the current secondary curriculum in terms of the inclusion or exclusion of human rights education? \\
\hline 8. & What are your perspectives regarding the use and/or misuse of power in society? \\
\hline 9. & What are your perspectives regarding t he use and/or misuse of power in education? \\
\hline 10. & What else would you like to share with me? \\
\hline
\end{tabular}

Table 3. Participants and Data Collection Process.

\begin{tabular}{|c|c|c|c|}
\hline Participants $^{\mathrm{a}}$ & $\begin{array}{c}\text { Medium of In- } \\
\text { terview }\end{array}$ & Number of Interviews and Length of Interview & Primary Data Yielded \\
\hline Ann & Skype and Email & One interview (approx 60 minutes); follow up emails & 13 page transcribed interview \\
\hline Beth & Skype & Two interviews - approx 1 hour (combined) & Three page transcribed interview \\
\hline Elizabeth & Skype and Email & One interview - approx 45 minutes; follow up emails & Five page transcribed interview \\
\hline Ernest & Emails only & Four email "interviews" & Three page transcribed interview \\
\hline Lynn & Skype and email & $\begin{array}{c}\text { One interview - approx 45 minutes (combined); follow } \\
\text { up emails }\end{array}$ & 14 page transcribed interview \\
\hline Michael & Skype & Two interviews - approx one hour (combined) & Eight page transcribed interview \\
\hline
\end{tabular}


Table 4.1. Participant Response Keywords and/or Themes.

\begin{tabular}{|c|c|c|c|}
\hline $\begin{array}{l}\text { Participant } \\
\text { Name }\end{array}$ & $\begin{array}{l}\text { Question 2: Sur- } \\
\text { vivor Testimony } \\
\text { Experience } \\
\end{array}$ & $\begin{array}{l}\text { Question 3: Survivor Testi- } \\
\text { mony Impact }\end{array}$ & Question 4: Why FWI Participant? \\
\hline Ann & $\begin{array}{l}\text { Nurturing, humility, } \\
\text { respect }\end{array}$ & $\begin{array}{l}\text { Forces me to recall the pain of } \\
\text { inhumanity; relate this to stu- } \\
\text { dents }\end{array}$ & $\begin{array}{l}\text { Heard Erin Gruwell speak - and believed in what she was } \\
\text { saying; was asked to participate }\end{array}$ \\
\hline Beth & $\begin{array}{l}\text { Energetic, positive, } \\
\text { calm }\end{array}$ & $\begin{array}{l}\text { Part of the whole FWI expe- } \\
\text { rience }\end{array}$ & $\begin{array}{c}\text { Was inspired to return to classroom after reading The } \\
\text { Freedom Writers Diary; wanted to use book in class to } \\
\text { reach at-risk students }\end{array}$ \\
\hline Elizabeth & $\begin{array}{l}\text { Inspiring, living } \\
\text { testament }\end{array}$ & $\begin{array}{l}\text { Importance of having survivors } \\
\text { speak to students to bring the } \\
\text { past to life }\end{array}$ & $\begin{array}{l}\text { Inspired by Diary, and wanted to develop ways to teach } \\
\text { tolerance and reach more students }\end{array}$ \\
\hline Ernest & $\begin{array}{l}\text { Hope for humanity, } \\
\text { warmth }\end{array}$ & $\begin{array}{c}\text { Share the experience and video } \\
\text { testimony with students }\end{array}$ & $\begin{array}{l}\text { Had Erin speak at juvenile hall, was inspired and was asked } \\
\text { to participate }\end{array}$ \\
\hline Lynn & $\begin{array}{l}\text { Inspiring, provides } \\
\text { hope }\end{array}$ & $\begin{array}{l}\text { Good can come from bad; to- } \\
\text { lerance transcends religious } \\
\text { faith; can accept and reach more } \\
\text { students in the classroom }\end{array}$ & $\begin{array}{c}\text { Saw Freedom Writers Diary movie, identified with Erin, } \\
\text { wanted to learn more from her }\end{array}$ \\
\hline Michael & $\begin{array}{l}\text { Emotional, uplift- } \\
\text { ing, positive }\end{array}$ & $\begin{array}{l}\text { Share what is acceptable beha- } \\
\text { vior with staff, and how we will } \\
\text { treat each other }\end{array}$ & $\begin{array}{l}\text { Heard Erin speak in his district, and applied; wanted to set } \\
\text { the tone as superintendent for teachers }\end{array}$ \\
\hline
\end{tabular}

Table 4.2. Participant Response Keywords and/or Themes.

\begin{tabular}{|c|c|c|}
\hline Participant & Question 5: FWI Influence as Educator & Question 7: HRE in Education \\
\hline Ann & $\begin{array}{l}\text { Love of people has been affirmed, supported and encouraged. } \\
\text { Becoming stronger disability rights activist. }\end{array}$ & $\begin{array}{c}\text { Valuing human life secondary or tertiary aspect of } \\
\text { education }\end{array}$ \\
\hline Beth & $\begin{array}{c}\text { Renewed hope in education; "unquit" teaching profession. } \\
\text { Willing to challenge status quo in education and put students } \\
\text { first. }\end{array}$ & $\begin{array}{l}\text { Complete absence of human rights in education - } \\
\text { unless brought in by individual teachers }\end{array}$ \\
\hline Elizabeth & $\begin{array}{l}\text { Renewed teaching faith - stayed in education - by being around } \\
\text { like-minded educators who want to make a difference in lives } \\
\text { of students }\end{array}$ & $\begin{array}{c}\text { Human rights is not explicitly covered; up to } \\
\text { individual teachers to incorporate any compo- } \\
\text { nents }\end{array}$ \\
\hline Ernest & $\begin{array}{l}\text { Love students more, and work in different ways to help them } \\
\text { learn }\end{array}$ & $\begin{array}{c}\text { Curriculum tries to be politically correct, instead } \\
\text { of giving all sides of an issue; human rights is } \\
\text { missing }\end{array}$ \\
\hline Lynn & $\begin{array}{l}\text { Learned to make students more active participants and get them } \\
\text { more engaged in the class. }\end{array}$ & $\begin{array}{l}\text { Did not feel well-qualified to answer the ques- } \\
\text { tion; HRE was a new term to her. }\end{array}$ \\
\hline Michael & $\begin{array}{l}\text { Walked away more student-centered, and passing that on to } \\
\text { teachers; moral calling }\end{array}$ & $\begin{array}{l}\text { No local or national educational standards for } \\
\text { teaching human rights }\end{array}$ \\
\hline
\end{tabular}

Because of its absence in the curriculum, educators have not necessarily been trained to understand and promote human rights. Five participants indicated that human rights education consisted of focusing on the following three themes: developing and promoting tolerance, ensuring the basic rights all human beings have, and treating others with respect. One participant, Lynn, stated, "I'm not well qualified to answer this [question] partially because the term, 'human rights education,' is new to me" (Lynn, personal communication, January 31, 2010). Overall, the five participants who answered shared a common belief that human rights education has not been mandated within their curriculum to any great extent, but felt it should be. While there may be a few units of study that lend themselves to a brief study of this topic, human rights education is not incorporated into the curriculum in any manifestation unless individual teachers are so inclined to include it in their classrooms.

The first experience of survivor testimony for many of the participants in the Freedom Writers Institute was their face-to-face encounter with Renée Firestone as she shared her story of survival in Auschwitz-Birkenau. All six participants in this study reported being deeply moved by her testimony, which positively impacted them as human beings and educators. Their descriptions were uniquely personal. Because of the different ways they described the experience, the participants seemed metaphorically to be revealing the different facets of a diamond.

In regards to the Freedom Writers Institute (FWI), this was also a positive experience for all participants. The unanimous belief was that they learned methods for better engaging their students, especially those who may be traditionally be considered "at-risk." While all six participants believed they had a positive relationship with their students prior to their participation in the FWI, the belief is that they now have an even stronger connection to their students. All six participants concluded that the methods and professional development of the Institute enabled and rejuvenated them 
to become further advocates of human rights education and social justice work.

Research has supported the belief that the historical events of the Holocaust have constituted a suitable context for teaching about human rights, the need for mutual respect, and tolerance (Cowan \& Maitles, 2007). When the Holocaust has been studied through the lens of human rights education, it has possessed the power to sensitize our students to the many dangers of indifference, intolerance and the dehumanization of others (Carrington \& Short, 1997; Lenhart \& Savolainen, 2003; Lindquist, 2007; Misco, 2008). Human rights education may have benefited students in terms of their social, emotional, ethical and intellectual development.

\section{Significance and Implications}

The inclusion of human rights education into the curriculum may serve to promote an appreciation of diversity as well as a stronger sense of community. As students learn about various human rights violations in the history of the world, they are better able to understand the fragility of those rights all people should enjoy. By learning about human rights abuses, students are better prepared to take a stand to prevent such abuses from happening again - and are more educated in identifying such infractions. Therefore, educators at all levels, including policy makers and politicians, need to address the current exclusion of human rights education within our school system. Until this is a core topic in our schools, the status quo will remain.

The testimony of Holocaust survivors has the ability to serve as a transformative tool in the lives of others. Through hearing of the atrocities of the Holocaust, individuals are confronted with the realities of our world's recent history, and are faced with the results of ignoring the basic human rights of others. Educators should encourage the use of survivor testimony to help bring the past to life as part of the inclusion of human rights education in the curriculum whenever possible and viable.

The Freedom Writers Institute (FWI) is a powerful and transformative professional development program for educators. It has been validated as a program that provides teachers with classroom techniques that have proven to be effective. Additionally, educators are strengthened and rejuvenated with the sense of "family" that is created by being a part of this program. This sense of family is not limited to the five days of the Institute, but is fostered and continues once the participants return to their respective communities. Administrators at all levels of the educational system need to encourage the promotion and involvement in this program. As teachers are trained during this Institute, they must be encouraged - perhaps with further, more intense training - to become teachers of teachers in their respective educational communities. A more effective means of promoting the Freedom Writer Institute's methods must be considered so that students are deliberately educated about morality in light of the living realities of people in their various communities.

\section{REFERENCES}

[1] Adalian, R. (2009). Armenian Genocide. [Online]. Available: $\mathrm{http}: / / \mathrm{www}$.armenian-genocide.org/genocide.html

[2] Andreopoulos, G., 2002, Human rights education and training for professional, International Review of Education, 48(3-4), 239-249.

[3] Arendt, H., 1958, The human condition, The University of Chicago Press, Chicago.

[4] Aronowitz, A., 2001, The last good job in America: Work and education in the new global technoculture, Roman \& Littlefield, New York.

[5] Bourdieu, P. \& Passeron, J., 1992, Reproduction in education, society and culture, Sage, London.

[6] Boyles, D., Carusi, T., \& Attick, D. Historical and critical interpretations of social justice, W. Ayers, T. Quinn, \& D. Stovall, Eds., New York, Routledge, 2009.

[7] Carr, W. \& Kemmis, S., 1983, Becoming critical: Knowing through action research, Deakin University, Victoria.

[8] Carrington, B., \& Short, G., 1997 November, Holocaust education, anti-racism and citizenship, Educational Review, 49(3), 271-283.

[9] Chyrikens, M. \& Vieyra, M., 2010, Making the past relevant to future generations: The work of the Anne Frank house in Latin America, Intercultural Communication, 21, 7-15.

[10] Cowan, P., \& Maitles, H., 2007, Does addressing prejudice and discrimination through Holocaust education produce better citizens?, Educational Review, 59(2), 115-130.

[11] Cresswell, J., 2007, Qualitative inquiry \& research design (2nd ed.), Sage Publications, Thousand Oaks.

[12] Dreier, P., 2006, Rosa Parks: Angry, not tired, Dissent, 53(1), 88-92.

[13] Foucault, M., 1972 The archeology of knowledge and the discourse on language, Pantheon Books, New York.

[14] Freire, P., 1970, Pedagogy of the oppressed, Seabury, New York.

[15] Freire, P., 2009, The critical pedagogy reader, A. Darder, M. Baltodano, \& R. Torres, Eds., New York, Routledge. Genocide Intervention Network (2009). Genocide in Darfur, Sudan. [Online]. Available: http://www.darfurscores.org/darfur

[16] Giroux, H., 1981, Ideology, culture and the process of schooling, Temple University Press, Philadelphia.

[17] Giroux, H., The critical pedagogy reader, A. Darder, M. Baltodano, \& R. Torres, Eds., New York, Routledge, 2009.

[18] Gordon, M., 2008, Toward a pedagogy of dissent, EN-COUNTER: Education for Meaning and Social Justice, 21(2), 20-27. 
[19] Gourevitch, P., The triumph of evil. [Online]. Available: http://www.pbs.org/wgbh/pages/frontline/shows/evil/intervie ws/gourevitch.html

[20] Greene, M., 1998, The dialectics of freedom, Teachers College Press, New York.

[21] Haas, P., 1998, Morality after Auschwitz: The radical challenge of the Nazi ethic, Fortress Press, Philadelphia.

[22] Habermas, J., 1979, Theory and practice, Beacon Press, Boston.

[23] Harrison, W., 2004, The man who shocked the world: The life and legacy of Stanley Milgram, Journal of Moral Education, 57(4), 1081-1084.

[24] Horkheimer, M., 1972, Critical theory, Seabury Press, New York.

[25] Jorgensen, G., 2006, Kohlberg and Gilligan: Duet or duel?, Journal of Moral Education, 35(2), 179-196.

[26] Kanpol, B., 1999, Critical pedagogy (2nd ed.), Bergin \& Garvey, Westport.

[27] Kohlberg, L., Moral education: It comes with the territory, D. Purpel \& K. Ryan, Eds., Berkeley, CA: McCutchan, 1976.

[28] Lenhart, V., \& Savolainen, K., 2002, Human rights education as a field of practice and of theoretical reflection, International Review of Education, 48(3-4), 145-158.

[29] Lindquist, D., 2007, September, Avoiding inappropriate pedagogy in middle school teaching of the Holocaust, Middle School Journal, 24-31.

[30] Lohrenscheit, C., 2002, International approaches in human rights education, International Review of Education, 48(3-4), 173-185.

[31] Marcuse, H., 1968, An essay on liberation, Beacon Press, Boston.

[32] McLaren, P., 1986, Schooling as a ritual performance, Rout-ledge, London.

[33] McLaren, P., Becoming and unbecoming White, C. Clark, \& J. O’Donnell, Eds., Westport, CT: Bergin \& Garvey, 1999.

[34] McLaren, P., The critical pedagogy reader (2nd ed.), A. Darder, M. Baltodano, \& R. Torres, Eds., New York, Routledge, 2009.

[35] McMillan, J., \& Schumacher, S., 2006, Research in education: Evidence-based inquiry (6th ed.), Pearson Education, Boston.

[36] McNeil, L., The critical pedagogy reader (2nd ed.), A. Darder, M. Baltodano, \& R. Torres, Eds., New York, Routledge, 2009.

[37] Mills, C.W., 2000, The power elite, Oxford University Press, New York.

[38] Misco, T., 2008, Teaching the Holocaust through case study. The Social Studies, 100(1), 14-22.
[39] Moncour, M. (2007). Quotation details. [Online]. Available: http://www.quotationspage.com

[40] North, C., 2008, What is all this talk about "social justice?" Mapping the terrain of education's latest catchphrase, Teachers College Record, 10(6), 1182-1206.

[41] Opotow, S., Gerson, J., \& Woodside, S, 2005, From moral exclusion to moral inclusion: Theory for teaching peace, Theory into Practice, 44(4), 303-318.

[42] Paul, R., 1992, Critical thinking: What every person needs to survive in a rapidly changing world, Foundation for Critical Thinking, Rohnert Park.

[43] Paul, R., and Elder, L., 2002, Critical thinking: Tools for taking charge of your professional and personal life, Pearson Education Upper Saddle River.

[44] Pekarsky, D., 1980, Moral dilemmas and moral education, Theory and Research in Social Education, 8(1), 1-8.

[45] Peterson, T. 2010, Moving beyond the toolbox: teaching human rights through teaching the holocaust in post-apartheid in South Africa. Intercultural Education, 21, 27-31.

[46] Polak, K., 2010, Tolerance education in Morocco. 'Anne Frank: A history for today: learning about our past - contributing to our future, Intercultural Communication, 21, 51-59.

[47] Print, M., Ugarte, C., Naval, C., \& Mohr, A., 2008, Moral and human rights education: The contribution of the United Nations, Journal of Moral Education, 37(1), 115-132.

[48] Rankin, A., 2006, Dietrich Bonhoeffer, a modern martyr: Taking a stand against the state gone mad, The History Teacher, 40(1), 111-122.

[49] Rummel, R., 1994, Death by government, Transaction Publishers, New Brunswick.

[50] Shapiro, J, \& Stefkovich, J., 2005, Ethical leadership and decision making in education: Applying theoretical perspectives to complex dilemmas (2nd ed.), Lawrence Erlbaum Associates, Mahwah.

[51] Shiman, D., \& Fernekes, W., 1999, The Holocaust, human rights, and democratic citizenship education, The Social Stu-dies, 90(2) 53-62.

[52] Shor, I. \& Freire, P., 1987, What is the "dialogical method" of teaching?, Journal of Education, 169(3), 11-31.

[53] Tibbits, F., 2002, Understanding what we do: Emerging models for human rights education, International Review of Education, 48(3-4), 159-171.

[54] United Nations, 1951, Convention Relating to the Status of Refugees, opened for signature 28 July 1951, 189 UNTS 150 (entered into force 22 April 1954).

[55] United Nations. (2010). The universal declaration of human rights.[Online].Available: http://www.un.org/en/documents/udhr/index.shtml 